\title{
Exploration of Computer Innovation and Entrepreneurial Talents Training Mode in the "Internet Plus" Age
}

\author{
Zhongshu Zhao \\ Liaoning University of International Business and Economics, Dalian, China \\ pzzs@163.com
}

Keywords: Internet Plus; Computer; Talent Cultivation

\begin{abstract}
Innovation and entrepreneurship education is the focus of the current higher education reform. Deepening innovation and entrepreneurship education is a breakthrough in promoting comprehensive reform of higher education, and is an important measure to promote higher quality innovation and entrepreneurship of college graduates. The arrival of the "Internet Plus" era has brought about a vast entrepreneurial space for computer practitioners. Therefore, this paper combines the development needs of the "Internet Plus" industry and proposes that the cultivation of computer professionals for innovation and entrepreneurial talents should focus more on the technology between computers and other disciplines. Integrate and use the Internet environment for practical promotion. It is particularly important to explore and study the computer-related professional innovation and entrepreneurship training model.
\end{abstract}

\section{Introduction}

Under the background of national innovation-driven development strategy, various new business models, new models, and new products have emerged, which have effectively stimulated social creativity and promoted the rapid development of the national economy. However, with the continuous increase in the demand for innovation and entrepreneurship, the cultivation mechanism of entrepreneurial and innovative talents is still not perfect. This contradiction has become the main reason for the low success rate of entrepreneurship. At the same time, colleges and universities, as the bases for personnel training, currently do not meet the needs of the double-invasion talents training in the educational model and education process. At the time of the training of talents, they have not completely shaken off the state of heavy theoretical knowledge and light practice. How can we develop double-creation talents that meet the needs of the country and society? This is a difficult problem for educators in higher education institutions. With the concept of "Internet Plus" proposed and the unprecedented combination of innovation and entrepreneurship in various fields, this gives the computer professional education a good opportunity to solve the problem of fostering double-creation talents. Therefore, we take the "Internet plus" environment as the orientation for the training of computer professionals for double-creation, with the goal of improving university students' awareness of innovation and entrepreneurship, and present a new model for the cultivation of innovative and entrepreneurial talents for computer majors.

\section{Computer Talent Training Orientation}

Colleges and universities are the bases for cultivating high-quality "applicable" talents, as well as an important base for knowledge innovation and an important part of the national innovation system. The training mode for innovative talents in computer science in universities should be constructed so that the cultivated talents have the ability to innovate, and there is a sense of bold reform and innovation.

Training Objectives. To nurture the Party's basic line, face the needs of production, construction, management, and service. It must be able to do the following, use it, use it quickly, and have strong practical skills. It has a cultural level and good professional ethics that are compatible with the profession. The man should master computer basic theory and basic skills, with computer hardware networking and debugging, as well as advanced technology application expertise for website 
construction and management.

Basic Requirements. Understand the basic principles of Mao Zedong Thought, Deng Xiaoping Theory, and the three important thinking ideology, have patriotism, good moral cultivation, and physical and mental qualities, strong legal concepts, and social responsibility. Grasp the basic science and technology theory and knowledge of the professional, have the technical application ability required by the main post of the major, immediately put up the post, solve the general technical problems in the post operation, and have certain ability of innovation. Some outstanding graduates, besides basic requirements, can more systematically master the basic theory and basic knowledge of the major, have strong professional skills or have high humanistic qualities, entrepreneurial abilities, and self-development stamina.

Career-oriented. In local government, enterprises and institutions, engaged in computer construction, management and maintenance, website development and management, sales and service of network software and hardware products, etc.

\section{Education Innovation and Entrepreneurship Overview and Current Situation}

Innovation and entrepreneurship education is based on cultivating the innovative spirit, entrepreneurial awareness, and innovation and entrepreneurship of college students. It is a practical education focusing on the cultivation of innovative thinking and entrepreneurial ability.The government report points out that colleges and universities are the bases for innovation and entrepreneurship. Higher education is the cornerstone for cultivating innovative and entrepreneurial talents. The cultivation of innovative and entrepreneurial talents depends to a large extent on the quality of innovation and entrepreneurship education in colleges and universities. At present, all major universities and colleges in China are actively exploring the integration of entrepreneurship and innovation education into the higher education system, and strengthening the construction of the entrepreneurship and innovation education curriculum system. Significant results have been achieved, but there are also some problems that need to be solved urgently:

Students' Awareness of Innovation and Entrepreneurship is not strong. Teachers are not good at Innovation Guidance and actively Create Conditions for Entrepreneurship. At present, on the one hand, due to the lack of necessary innovation and entrepreneurial education and the influence of traditional culture, the objectives of innovation and entrepreneurship are still blurred.On the other hand, some teachers did not implement innovation and entrepreneurship education in the course of curriculum education. They felt that the problem of quality of students had caused the traditional teaching quality to be difficult to guarantee and that innovation and entrepreneurship education could not be carried out.

Innovation and Entrepreneurship Training model is not yet Perfect. Although various universities and colleges have issued many incentive policies and measures for innovation and entrepreneurship, they have not clearly defined the status of innovation and entrepreneurship education in the talent training model, but have only partially corrected and supplemented the traditional training model.

In the curriculum system, traditional courses are still the mainstay. There is a lack of organic links between curriculum settings and the lack of emphasis on cross-discipline application teaching. As a result, students have less opportunities to access the frontiers of various disciplines and lack the theoretical knowledge to support innovation and entrepreneurship. They unable to actively discover new modes of innovation and entrepreneurship.

Students Lack Powerful Internal Motivation and Goal Orientation for Innovation and Entrepreneurship. At the present stage, there are common follow-up study habits among college students, which have a single way of thinking, lack flexibility and comprehensiveness, and greatly limit the cultivation of innovative thinking ability. In addition, in the teaching process, most courses still use the traditional assessment system and assessment method based on a single assessment model, and lack of innovative evaluation standards. This has also become a bottleneck in the implementation of innovation and entrepreneurial talents, and hinders the improvement of personnel capabilities and quality. 
The Backward Practice Teaching System Hinders the Advancement of Innovation and Entrepreneurship Education. Most of the existing practical teaching links are partial verification experiments of known knowledge. Even if independent experiments are conducted, it is also a comprehensive experiment of traditional knowledge. It does not attach importance to cultivating students' independent practical ability for practical problems in emerging fields. Therefore, it is difficult to form the ability of innovation and entrepreneurship. In order to make innovation and entrepreneurship education more closely integrated with professional characteristics and to exert better talent training results. In the "Internet Plus" environment, the article takes the reform of innovation and entrepreneurial talents training mode as the starting point, takes the fostering of computer students' innovation awareness and entrepreneurial ability as research objectives, actively explore measures such as curriculum reform, innovation and competition construction of science and technology groups, and integration of entrepreneurial platforms within and outside the university, so as to cultivate excellent dual-innovation computer professionals.

\section{Under the Background of Internet Plus Computer Professional Innovation and Entrepreneurship Training Map}

Innovate the talent cultivation mode, focus on cultivating students' practical ability, present the path and content of professional practice ability development in the form of a clear and clear road map, with strong pertinence and operability. From the student's point of view, the road map is like a navigation map of ability. From the figure, you can see what kind of skills are required to cultivate innovative entrepreneurship and what skills to learn. The teacher will also form a clear teaching coordinate system in the roadmap to clarify whether the taught curriculum and teaching environment meet the training objectives.

\section{Research on the Training Mode of Innovation and Entrepreneurship Talents in Computer Specialty in the Internet plus Era}

Optimize the Computer Professional Curriculum System with Innovative Entrepreneurial Ideas. $\mathrm{t}$ is necessary to construct the curriculum system of innovation and entrepreneurship education for computer majors, and also to absorb innovation and entrepreneurship education elements in the professional curriculum system.

The practice can be simply summarized as follows: Compulsory courses and elective courses in the innovation and entrepreneurship courses are carried out throughout the university curriculum. In the lower grades, some entrepreneurial basic courses are taught in the form of classroom teaching or lectures, and the awareness of innovation and entrepreneurship is cultivated, and simulations are used in the senior year, to enhance the ability of innovation and entrepreneurship; In the course of professional courses, we will introduce courses that introduce cutting-edge technologies in computer science and entrepreneurial cases in the computer field.In addition, we must add some comprehensive interdisciplinary courses to broaden our knowledge and discover what kind of business opportunities and innovations will be brought about by the convergence of the computer field and other fields in the context of the "Internet Plus" era.

Relying on Computer majors, launching Education for Creating Passengers and Building a positive Innovation and Entrepreneurship Education Environment. The main task of maker education is to cultivate students' innovative awareness, innovative thinking, innovative quality and basic innovation capabilities, and lay a solid foundation for future employment and entrepreneurship. The idea of building a computer maker education can be implemented in the following aspects.

(1) Create studios or workshops that are suitable for the creative realization of computer students, such as robot studios, advertising design studios, etc.

(2) In the student education process, it is possible to develop related learning and training programs and integrated teaching materials, such as computer courses, single-chip microcomputers and $\mathrm{C}$ language teaching materials, and to create robot studios based on services. 
(3) Construct a self-learning curriculum model. Maker education adopts an open organization method, independent learning, students are free to group, according to the project implementation, a teacher to guide one or several projects

Develop School-industry Cooperation and Cultivate highly Skilled Composite talents. Break through the traditional school-enterprise cooperation model and create a business school named after the company's name. The two sides jointly cultivate talents, research and develop new products, apply for scientific research projects and technical patents, and even name the company in the class, and one company employee serves as the part-time class teacher.Classes and companies regularly conduct business class meetings, professional trends and career planning lectures, so that students can not only learn professional knowledge, but also can feel the company's culture in advance, and cultivate innovative entrepreneurial accomplishments in real enterprise practice.

Inspire Students to Participate in Various Disciplines and Skills Training and Competitions. Participating in innovative entrepreneurial competitions and related trainings Participating in the Innovation and Entrepreneurship Contest can not only cultivate college students' sense of responsibility and innovation, but also improve their ability to solve practical problems, improve their professional skills, and exercise their ability to express themselves and their lives. It is an effective practical teaching link for all-round cultivation of innovative and entrepreneurial talents. Students' innovative ideas and practical operations are run through each other in the realization of products or works, thereby transforming students' innovative potential into innovative capabilities.

In the constant exploration of creation, various problems and setbacks may be encountered. This requires students to find information, test repeatedly, ask people for advice, or jointly develop with the team. Through such a process of creation, students will fundamentally To exercise their own innovation and cooperation abilities, they have also formed a good character and endurance. Innovation and entrepreneurship training can also allow students to broaden their horizons, increase their knowledge, understand the most advanced business trends, and understand the direction of their professional development. Students should always pay attention to the new trends in innovation and entrepreneurship, new policies, and find new ways for their own innovation and entrepreneurial learning and development. Quasi-directional.

Faculty Construction. Both professional theoretical basis and teaching experience, as well as rich professional experience, this kind of "double-qualified" teacher team is the basic requirement for innovation and entrepreneurship education.For a teacher, he not only possesses a certain theoretical level, but also needs a certain amount of scientific research capabilities. For example, he has obtained patents, obtained projects (or projects) at or above the provincial level, and participated in enterprise technical engineers as part-time teachers for innovative entrepreneurship courses. The rich engineering experience and superb technical skills of corporate teachers have brought great help to innovation training and innovation practice, and enriched the teaching content of innovation and innovation classes.

\section{Summary}

With the arrival of the Internet era, the "Internet Plus" and innovative entrepreneurial talents training model as an entry point, and the goal of training computer majors to develop innovative entrepreneurial skills based on Internet thinking. Fully promote the dual-creation reform of computer professional education, and establish a set of dual-creation computer talents training mode in the era of "Internet Plus".It can effectively improve the professionalism and scientific quality of computer major students, and further stimulate students' enthusiasm to actively participate in various innovative and entrepreneurial practice activities. It is of great significance to realize the leap-forward development of computer innovation and entrepreneurial personnel training and to realize the coordinated development of the "Internet Plus" talents training, and it also provides strong support for the training of computer professional innovative talents with international competitiveness. 


\section{References}

[1] Miles I. e-Development Toward the Knowledge Economy: Leveraging Technology, Innovation and Entrepreneurship for 'Smart' Development. Edited by Elias G. Carayannis and Caroline M. Sipp[J]. R \& D Management, 2010, 37(3):277-278.

[2] Fang Y, Wang X, Lifeng X I, et al. Innovation and Entrepreneurship Training as the Core for Reform of Computer Science Curriculum[J]. Computer Education, 2011.

[3] Science C. Social Entrepreneurship and Social Innovation[J]. Sourceoecd Science \& Information Technology, 2010, volume 2010:176-208(33).

[4] Jervan G, Ellervee P, Kruus M. Innovation and entrepreneurship in the computer systems curricula and Nordic Master School in Innovative ICT[C]// Eaeeie Conference. IEEE, 2011:1-4.

[5] Uzunidis D, Laperche B. Innovation Systems and Entrepreneurship[M]. Springer New York, 2013.

[6] Cruz E F Z D, Alvaro A. Introduction of entrepreneurship and innovation subjects in a computer science course in Brazil[C]// Frontiers in Education Conference. IEEE, 2013:1881-1887.

[7] Siricharoen W V. International Journal of E-Entrepreneurship and Innovation (IJEEI)[J]. express shipping*, 2010.

[8] Petrakis P E, Kostis P C. Medium term effects of culture, transactions and institutions on opportunity entrepreneurship[J]. Journal of Innovation \& Entrepreneurship, 2014, 3(1):1-22.

[9] Yadav V, Goyal P. User innovation and entrepreneurship: case studies from rural India[J]. Journal of Innovation \& Entrepreneurship, 2015, 4(1):5.

[10] Bielenia-Grajewska M, Carayannis E G, Campbell D F J. Linguistic Dimension of Creativity, Invention, Innovation, and Entrepreneurship[J]. Encyclopedia of Creativity Invention Innovation \& Entrepreneurship, 2013, 7(1):77-78.

[11] Househ M, Alshammari R, Almutairi M, et al. Building a Culture of Health Informatics Innovation and Entrepreneurship: A New Frontier.[J]. Stud Health Technol Inform, 2015, 213:237-240.

[12] Cunningham P. Insights into open innovation and ICT entrepreneurship in Africa[C]// IEEE International Symposium on Technology and Society. IEEE, 2016:1-8.

[13] Xuan C X, Ying W, Amp I. Exploration on Fusing Innovation and Entrepreneurship Education With Computer Courses Hierarchically and Progressively[J]. Computer Knowledge \& Technology, 2017.

[14] Zhao Z, Tiefeng W U, Lili H E. Research on Innovation and Entrepreneurship Training Mode of Computer Major Students in Universities[J]. 2018(adess). 